\title{
Fluoroscopically guided transforaminal epidural catheterization of the ankylosing spondylitis
}

\author{
Ankilozan spondilitli olguda floroskopi eşliğinde transforaminal epidural kateter
}

\author{
(1) Sema ŞANAL BAŞ,' 도 Sacit Mehmet GÜLEÇ²
}

\begin{abstract}
Summary
Ankylosing spondylitis (AS) is a chronic, progressive, autoimmune collagen tissue disease characterized by inflammation and lower back pain. General anesthesia may pose a high risk in the AS due to intubation difficulty, as well as affected respiratory and cardiovascular organs. In cases of involvement of the vertebrae, neuraxial anesthesia may be difficult or even impossible. In this article, we discuss a case of AS that received a successful an epidural catheter was placed using a transforaminal route under C-arm fluoroscopy guidance for total hip replacement surgery, which was difficult due to intubation and an interlaminar neuraxial anesthesia.
\end{abstract}

Keywords: Ankylosing spondylitis; epidural; fluoroscopy; transforaminal.

\begin{abstract}
Özet
Ankilozan spondilit (AS), enflamatuvar bel ağrısı ve sakroileit ile karakterize kronik, progresif ve otoimmün bir kollajen doku hastalığıdır. Bu hasta grubunda, zor hava yolunun yanında solunum, kardiyovasküler organ tutulumları nedeniyle genel anestezi uygulaması yüksek riskli olabilir. Vertabra tutulumu olduğunda ise nöroaksiyel blok zor ya da imkansız hale gelebilir. Total kalça protezi yapılan, AS nedeniyle entübasyon güçlüğü olan ve interlaminar nöroaksiyel blok imkansız gibi görünen bir olguda floroskopi eşliğinde transforaminal yoldan epidural kateter yerleştirilerek yapılan başarılı bir epidural anestezi uygulamasını tartıştık.

Anahtar sözcükler: Ankilozan spondilit; epidural; floroskopi; transforaminal.
\end{abstract}

\section{Introduction}

Ankylosing spondylitis (AS) is a chronic, progressive and autoimmune collagen tissue disease. The inflammation in the joints causes progressive degenerative osteoarthritis. ${ }^{[1]}$ In this article, we discuss a case of AS that received a successful epidural catheterization and anesthesia in for total hip replacement surgery, which was made difficult due to intubation and an interlaminar neuroaxial anesthesia via transforaminal route under fluoroscopy guidance. To our knowledge, there is no such report in the literature.

\section{Case Report}

A fifty year old male patient, weighing $85 \mathrm{~kg}$ and $167 \mathrm{~cm}$ tall, presented to the orthopedics outpatient clinic. He was diagnosed with coxarthrosis of the left joint, and total hip replacement surgery was planned.
The patient had a history of ankylosing spondylitis for 20 years. He developed congestive heart failure, restrictive type lung disease, and uveitis at the left eye during the previous year. In his physical examination, there was postural deformity, and his left hip joint had a 30-degree flexion posture with no active or passive motion possible. His muscle strength at his bilateral lower extremities was 4/5. In the head and neck examination, he had impaired vision in his left eye; mouth opening range was 2-cm; thyromental distance measured $4-\mathrm{cm}$, sternomental distance measured 6- $\mathrm{cm}$; and there was limited motion in his extension (40 degrees) and flexion (10 degrees) of the neck. The Mallampati score was assessed as class III. Vertebral radiogram revealed squaring of vertebral bodies, and bamboo spine appearance and due to syndesmophytes (Figure 1). Written informed consent was obtained from the patient after that the pa-

\footnotetext{
'Department of Anesthesiology and Reanimation, Eskişehir Osmangazi University Faculty of Medicine, Eskişehir, Turkey

2Division of Algology, Department of Anesthesiology and Reanimation, Eskişehir Osmangazi University Faculty of Medicine, Eskişehir, Turkey

Submitted: 08.02.2018 Accepted after revision: 11.04.2018 Available online date: 04.10.2018
}

Correspondence: Dr. Sema Şanal Baş. Meşelik Kampüsü, Eskişehir Osmangazi Üniversitesi Tıp Fakültesi Hastanesi, Anesteziyoloji Sekreterliği, Odunpazarı, 26480 Eskişehir, Turkey.

Phone: +90 - 222 - 2392979 / 5007 e-mail: drsemasa@gmail.com

(c) 2020 Turkish Society of Algology 


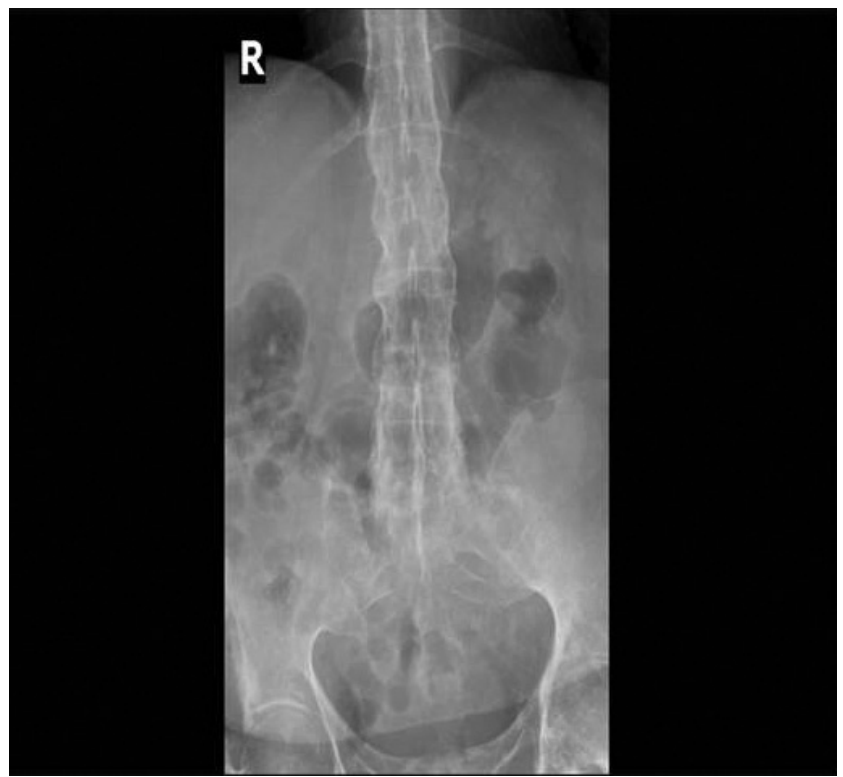

Figure 1. Patient vertebral radiogram.

tient was taken to the operating. Premedication was not administered. Before anesthesia administration, equipment was checked, including a LMA fastrach, gum elastic bougie, a videolaryngoscopy, a tracheostomy tray. We decided to the patient of epidural catheterization via fluoroscopic guided (Plan A). Accidental dural puncture could be recognized with cerebrospinal fluid, we would place the catheter into the subarachnoid space for continuous spinal anesthesia (Plan B). We would performed the general anesthesia if the administration of epidural anesthesia could been respiratory insufficiency or failed neuroaxial block (Plan C).

The patient was positioned prone, a betadine-based solution is spread over the skin in circular fashion, and sterile drapes applied. After under C-arm-fluoroscopy guidance, an 18-gauge Tuohy needle was advanced through the lumbar (L) 4-5 space with a 20 degree oblique angle until the intervertebral foramen. Confirming the position of the tip of the needle at intervertebral foramen using anteroposterior (AP) and lateral fluoroscopic images, an epidural catheter was placed in the epidural space by inserting through a Tuohy needle.

After negative aspiration for cerebrospinal fluid and blood, non-ionic contrast material iohexol (Omnipaque) was injected $(3 \mathrm{ml})$ from the catheter in fractions, and the catheter was confirmed to be in the epidural space using AP and lateral fluoroscopic images (Figure 2). The catheter was advanced to the

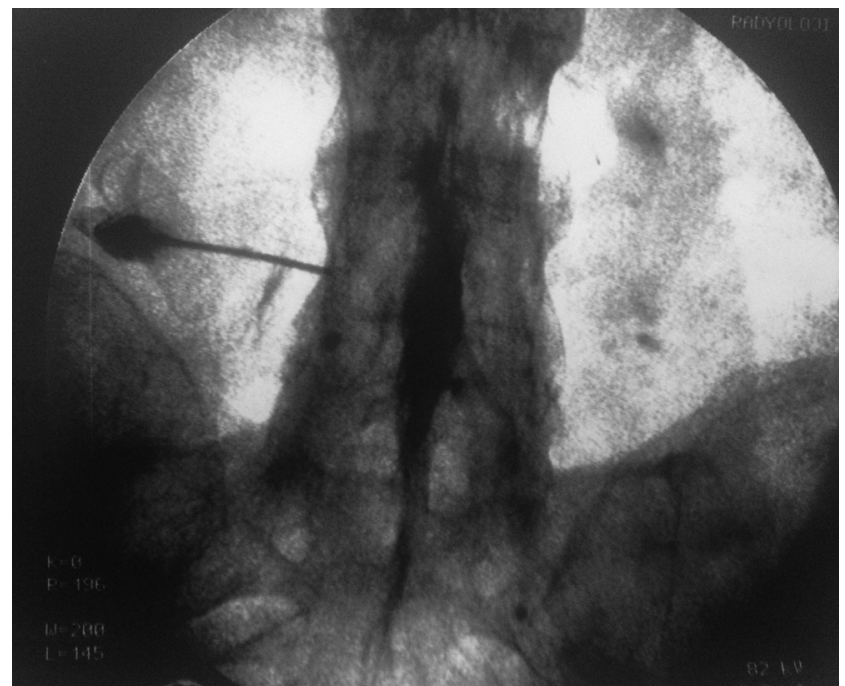

Figure 2. Epidural cathaterLateral fluoroscopic images.

upper part of $\mathrm{L} 3$ vertebra level. The patient was then positioned supine, and $3 \mathrm{ml}$ (lidocaine 1.5\% and 1:200,000 epinephrine) was injected as epidural test dose. Following confirmation of the catheter's place, $12 \mathrm{ml}$ of a $0.5 \%$ isobaric bupivacaine was injected in fractions. When the blockade level reached T8, the patient was positioned properly and the operation was initiated. The operation lasted 4 hours. The patient required a local anesthetic dose twice until the end of the operation, and a total of $20 \mathrm{ml}$ of a $0.5 \%$ isobaric bupivacaine was administered during the operation. During 2 postoperative days, the patientcontrolled epidural analgesia was continued. On the $6^{\text {th }}$ day, the patient was discharged from the orthopedics ward with recommendations.

\section{Discussion}

General anesthesia may pose high risk in patients with AS because of the known respiratory problems, cardiovascular organ involvement, and difficulty with intubation. ${ }^{[1,2]}$ Although neuroaxial anesthesia seems to be a great alternative, narrow epidural space and ossifications in ligamentum flavum can cause application challenges and even make the blockade impossible. ${ }^{[1-3]}$ We describe a case of epidural catheterization via transforaminal route under fluoroscopy guidance from ankylosing spondylitis undergoing total hip replacement surgery.

Technical difficulties are also increase the risk of complications, including spinal hematoma. Epidural catheter placement may be technically difficult due to restricted flexion of the lumbar spine and ossifica- 
tion of interspinous ligaments and it often leads to complete failure. Neuroaxial blocks are technically challenging and local anesthetic toxicity due to intravascular injection or an unpredictable level of anesthesia for epidural injection. ${ }^{[4]}$

Fluoroscopically guided transforaminal epidural steroid injection is administered for treatment of a chronic radicular lower limb pain. ${ }^{[5,6]}$ Major and minor complications regarding transforaminal epidural steroid injection applications were reported in the literature. Transforaminal injection of minor and major complications include vasovagal reaction, dural puncture, intradiscal injection, infections, bleeding (epidural hematoma, spinal hematoma). There are also neurological complications such as stroke, spinal cord injury, arachnoiditis which are associated with epidural steroid injection not transforaminal technique. ${ }^{[7]}$

However, there is no data on utilization of transforaminal epidural catheterization for surgical purposes under fluoroscopy guidance. Only the one case report, 23 gauge quinkeys spinal needle was inserted under fluoroscopically guided transforaminal single shot epidural injection for ureteroscopic stone removal. ${ }^{[4]}$ We used to achieve in patients with AS by epidural catheterization via transforaminal route under fluoroscopy guidance and a successful anesthesia management during the surgery.

Anatomical changes that occur in AS, such as fusion of lumbar vertebrae, narrow interlaminar arena and calcification of posterior longitudinal ligament, adequate mouth opening. ${ }^{[8-10]}$ These changes can lead difficulty management of airway and epidural or spinal anesthesia so that alternative managements can used the patient. Peripheral nerve blocks have performed successfully of guided ultrasound (US) and fluoroscopy. But US guided is not gold standard for deeper structures and spinal procedure. And it can performed with guided computed tomography or fluoroscopic performs the gold standard in the lumbar spine. ${ }^{[11-14]}$ So we decided to perform epidural catheterization via guided fluoroscopy and management of epidural anesthesia was successful.

Intubation assist methods such as awake fiberoptic intubation and video laryngoscopy can be used to overcome the difficulties in patients performed general anesthesia with AS..$^{[9,12-14]}$ According to one previous report, they could not perform neuroaxial anesthesia in one case due to ossification of the ligamentum flavum in the lumbar vertebrae and narrowing of the interlaminar entry area. Ankylosing spondylitis can lead to difficulty in neuroaxial anesthesia to change of ossified vertebral column and narrowed intervertebral spaces. Narrowing of interlaminar area can lead to traumatic complication such as difficult transforaminal catheterization, direct vascular damage secondary to needle replacement, and nervous root injury irritation. ${ }^{[10]}$ We did not have any technical difficulties or any complication in our case.

In conclusion, we showed that a successful neuroaxial anesthesia can be relatively safe alternative in patients with AS by epidural catheterization via transforaminal route under fluoroscopy guidance. Therefore, it should be performed by an experienced physician or under the guidance of an experienced technician and radiologic imaging must be used. It should be kept in mind that management of a case of ankylosing spondylitis can be very challenging as the airway and the central neuraxial blockade are extremely difficult. The anesthesia management should be planned an alternative option for airway management and fluoroscopy may lead to predictable success in the AS of transforaminal epidural catheterization.

Informed Consent: Written informed consent was obtained from the patient for the publication of the case report and the accompanying images.

Conflict-of-interest issues regarding the authorship or article: None of the authors had conflicts of interest in relation to this study or was provided funding by the manufacturer.

Peer-rewiew: Externally peer-reviewed.

\section{References}

1. Chen L, Liu J, Yang J, Zhang Y, Liu Y. Combined Fascia Iliaca and Sciatic Nerve Block for Hip Surgery in the Presence of Severe Ankylosing Spondylitis: A Case-Based Literature Review. Reg Anesth Pain Med 2016;41(2):158-63. [CrossRef]

2. Schelew BL, Vaghadia H. Ankylosing spondylitis and neuraxial anaesthesia--a 10 year review. Can J Anaesth 1996;43(1):65-8. [CrossRef]

3. Wulf $\mathrm{H}$. Epidural anaesthesia and spinal haematoma. Can J Anaesth 1996;43(12):1260-71. [CrossRef]

4. Channabasappa SM, Dharmappa S, Pandurangi R. Fluoroscopy guided transforaminal epidural anesthesia in anky- 
losing spondylitis. Saudi J Anaesth 2016;10(1):101-3.

5. Irwin RW, Zuhosky JP, Sullivan WJ, Foye PM, Sable AW, Panagos A. Industrial medicine and acute musculoskeletal rehabilitation. 5. Interventional procedures for work-related lumbar spine conditions. Arch Phys Med Rehabil 2007;88(3 Suppl 1):S22-8. [CrossRef]

6. Manchikanti L, Malla Y, Wargo BW, Cash KA, Pampati V, Fellows B. A prospective evaluation of complications of 10,000 fluoroscopically directed epidural injections. Pain Physician 2012;15(2):131-40.

7. Bicket MC, Chakravarthy K, Chang D, Cohen SP. Epidural steroid injections: an updated review on recent trends in safety and complications. Pain Manag 2015;5(2):129-46.

8. Bajwa SJ, Bajwa SK, Kaur J, Singh BA, Prasad S. Anaesthetic management of a vaginal hysterectomy case with an unanticipated failure of epidural injection due to fused lumbar spine. Int J Appl Basic Med Res 2011;1(1):57-9.

9. Lili $X$, Zhiyong $H$, Jianjun $S$. A comparison of the GlideScope with the Macintosh laryngoscope for nasotracheal intubation in patients with ankylosing spondylitis. J Neurosurg Anesthesiol 2014;26(1):27-31. [CrossRef]

10. Hoffman SL, Zaphiratos V, Girard MA, Boucher M, Crochetière $C$. Failed epidural analgesia in a parturient with advanced ankylosing spondylitis: a novel explanation. Can J Anaesth 2012;59(9):871-4. [CrossRef]

11. Korbe S, Udoji EN, Ness TJ, Udoji MA. Ultrasound-guided interventional procedures for chronic pain management. Pain Manag 2015;5(6):465-82. [CrossRef]

12. Leung KH, Chiu KY, Wong YW, Lawmin JC. Case report: Spinal anesthesia by mini-laminotomy for a patient with ankylosing spondylitis who was difficult to anesthetize. Clin Orthop Relat Res 2010;468(12):3415-8. [CrossRef]

13. Turgut Balcı Ş, Türköz A, Çınar Ö, Bircan HY, Sekmen Ü. Alternative anaesthetic management in ankylosing spondylitis. Agri 2014;26(4):196-7. [CrossRef]

14. Aydeniz A, Akaltun MS, Gür A, Gürsoy S. Coexistence of polymyalgia rheumatica with ankylosing spondylitis: $A$ case report. Agri 2018;30(1):35-7. [CrossRef] 